\title{
Process of design an eco-friendly catamaran to extract aquatic plants
}

Proceso de Diseño de un Catamarán eco-amigable para extraer plantas acuáticas

DOI: https://doi.org/10.25043/19098642.189

Leonardo Abel Ponce Adriazola ${ }^{1}$ Jose Luis Mantari ${ }^{2}$

\begin{abstract}
This paper presents the design of an eco-friendly catamaran that follows two design methodologies, one focusing in the importance in the needs of future users and the other the spiral boat design methodology. The project is going to take advantage of the unique form of a catamaran and use the space available between the points of flotation for the process of extracting small plants and light plastics from the surface of recreational lakes. With the project the esthetics and also the aquatic ecosystem of the lake would be better preserved. The application of the project, could improve the time required to recollect the duckweed and only required one operator; however, the potential of the project is significantly bigger as it could be used as a method to extract superficial contaminants in 'garbage patches' in the ocean and lakes without harming the species that still are in the zone of operation. Good practices of engineering are going to be use for the design of the catamaran, as well as for the selection of the necessary components.
\end{abstract}

Key words: Design, catamaran, eco-friendly, spiral design methodology.

\section{Resumen}

El presente artículo científico presenta el diseño de un catamarán eco-amigable que sigue dos metodologías de diseño, una que se centra en la importancia de las necesidades de futuros usuarios y la metodología en espiral centrada en el diseño de embarcaciones. La propuesta aprovecha la forma única de un catamarán y utiliza el espacio disponible entre los puntos de flotación para el proceso de extracción de pequeñas plantas e plásticos ligeros de las superficies acuáticas en lagos recreativos. Con el funcionamiento del proyecto se busca mejorar la estética y también el ecosistema acuático en lagos, a la vez se mejoraría el tiempo requerido para recolectar la lenteja de agua, además de solo requerir de un operador; sin embargo, el potencial de este proyecto es significativamente mayor, ya que podría utilizarse como un método para extraer contaminantes superficiales en islas de basura en océanos o lagos sin dañar a las especies que aún se encuentran en la zona de operación. Se utilizarán buenas prácticas de ingeniería para el diseño del catamarán, así como para la selección de los componentes necesarios.

Palabras claves: Diseño, catamarán, eco-amigable, metodología diseño en espiral.

\footnotetext{
${ }^{1}$ Mechanical Engineer Department, Universidad de Ingeniería y Tecnología Lima, Perú. Email: leonardo.ponce@utec.edu.pe

${ }^{2}$ Mechanical Engineer Department, Universidad de Ingeniería y Tecnología Lima, Perú. Email: jmantari@utec.edu.pe
} 


\section{Introduction}

Nonmoving water always cause certain problems in recreational lakes or in considerable size open field deposit of water, where an aquatic plant named duckweed manages to grow due to bacteria presence [14]. The main problem with this plant is that it doesn't allow the sunlight to enter to the aquatic environment, degrading the ecosystem and also because his fast decomposition it generates not pleasant smells [14]. The plant is necessary in the lake in order to maintain the food chain in the aquatic ecosystem, however his overpopulation bring the previously mentioned problems.

Currently, in recreational lakes, the duckweed doesn't give a good aspect when the lake is opened to the visitors, the way of removed it is manually by at least 2 employees, taking at least six labor hours (Number given by the City Hall of Santiago de Surco).
An eco-friendly catamaran with an extraction system could clean a lake in a at least $40 \%$ faster way, without making a lot of noise [1].

The objective of the project is to learn, design and simulate an eco-friendly vessel capable of recollect superficial plants; this means that the ways of generate power and the material of the hull constructions had to be ecological.

\section{Design Methodology}

In the design process of any type of boat, there is always going to be certain problems such as re-design the boat structure or changing the dimensions when the weight distribution of the components is already done. So is important to keep in mind the spiral methodology [1], [15].

Fig. 1. Spiral design methodology mostly used in boats [1]

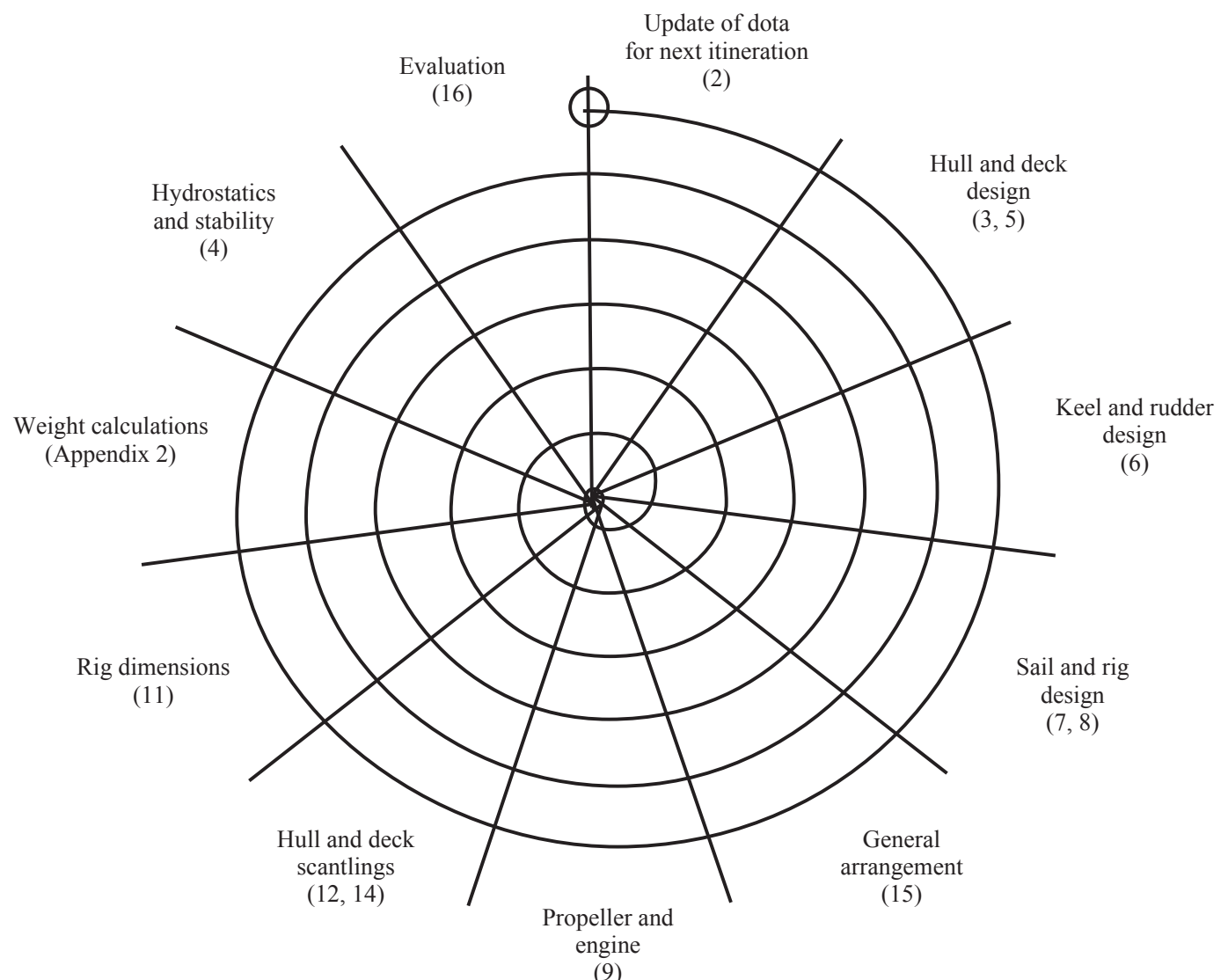

(9) 


\section{Functional Analysis}

Knowing the principal objective of the project, is important to collect and measure certain necessities from a possible customer. In this case the hall of Santiago de Surco - Lima which administrate a recreational lake called "Lago de la Amistad", manifest that the vessel should accomplish certain necessities to them being interested in used it, Table 1 .

\section{The white box}

The methodology offers the option to perform the analysis of the white box, this helps to consider the objectives of the project and focusing entirely in solving them. The box in Fig. 2 stablishes as input data (the problems to solve) and an output data (the project objectives). Inside the "white box", are the variables to succeed with the input data. Using the white box guarantees the usability of the project [15].

\section{Preliminary considerations}

One initial step in the spiral methodology in vessel is to select the type of boat looked-for to achieve the necessities. A catamaran was the most suitable option due his unique form, his reduce draught compared with a monohull $(33.3 \%$ better) and his $15 \%$ superior transversal stability [5], [7].

Table 1. Necessities charts.

\begin{tabular}{|c|c|c|c|c|c|}
\hline Necessities & Metric & Units & Value & Importance & $\begin{array}{c}\text { Should / } \\
\text { Shouldn't Have }\end{array}$ \\
\hline $\begin{array}{l}\text { Eco friendly } \\
\text { materials }\end{array}$ & $\begin{array}{l}\text { Construction with } \\
\text { natural fibers }\end{array}$ & $\mathrm{kg}$ & $8-14$ & HIGH & Should \\
\hline $\begin{array}{c}\text { Low cost of } \\
\text { operation }\end{array}$ & $\begin{array}{l}\text { Operation with } \\
\text { renewable energy }\end{array}$ & $\$$ & 0.5 & HIGH & Should \\
\hline Easy to maneuver & On a catamaran & $\begin{array}{l}\text { Turning } \\
\text { radius }\end{array}$ & $20^{\circ}-45^{\circ}$ & MEDIUM & Should \\
\hline Few Components & $\begin{array}{l}\text { In motors and solar } \\
\text { panels }\end{array}$ & Quantity & $4-10$ & HIGH & Should \\
\hline Stable & - & - & - & HIGH & Should \\
\hline Safe & With safety standards & Level of risk & 3 & HIGH & Should \\
\hline Light Weight & Over all weight & $\mathrm{kg}$ & $20-40$ & LOW & Should Not \\
\hline Quiet & In operation & decibels & 30 & MEDIUM & Should \\
\hline
\end{tabular}

Fig. 2. White box diagram.

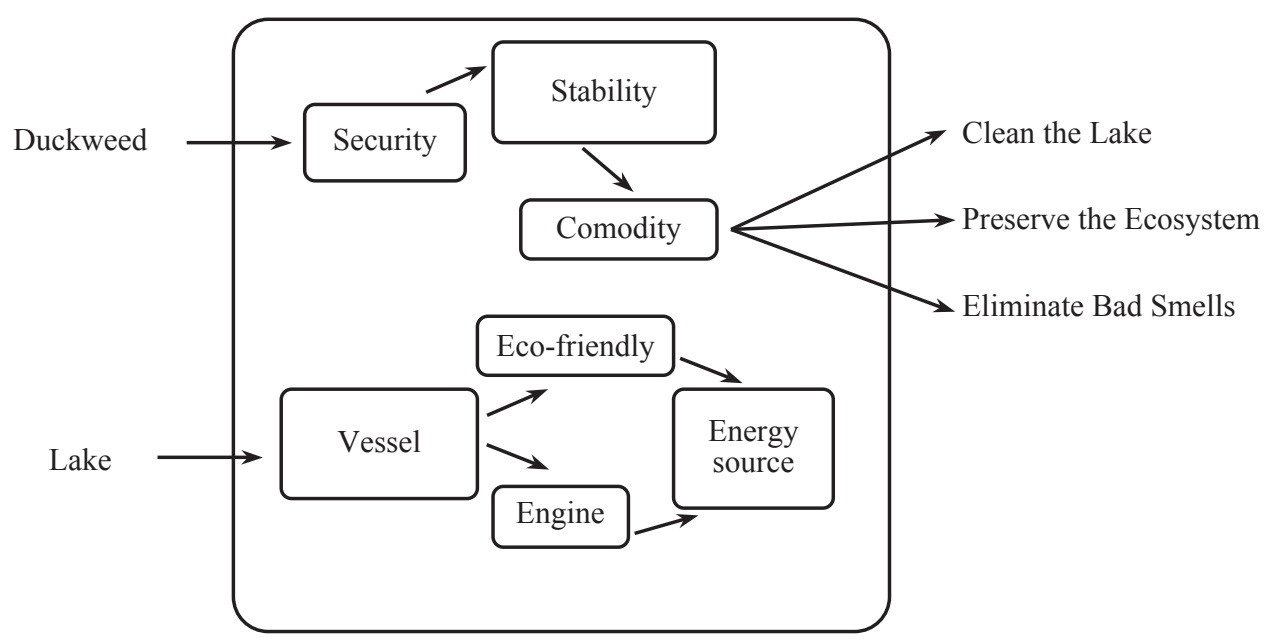


Fig. 3. Symmetrical catamaran [9].

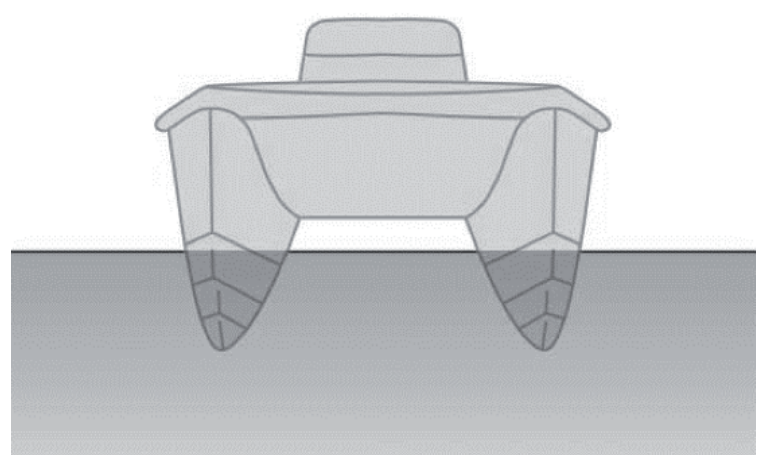

Also in this part is important to know the type of propulsion the boat would use, due to the objective and requirements of the consumer (Table 1) an electric motor is the best option.

\section{Hull Geometry}

In the industry there are two types of hulls the displacement and planning hull. The first one is designed to go through the water and second one is designed to glide on the surface of the water as the boat gains speed [2]. Since the objective of the project is to extract aquatic plants, both hulls of the catamaran are being the displacement type.

Once establishing the type of hull, the next thing is to select the hull style, in the industry they use different types like round bottom, flat bottom, $\mathrm{v}$ bottom and other; for the project was selected a multi displacement hull with convex round bottom style, because it present better longitudinal stability, better pressure resistance and more displacement capacity [12].

\section{Lines drawing}

The first step before start designing the catamaran is to establish the dimensions, where the facts considered were, the maximum lengths value of a design category, the amount of duckweed estimated to recollect and an analysis of the dimensions of the boat commonly found in recreational lakes [3], [4].

Table 2. Vessel dimension.

\begin{tabular}{|c|c|c|c|}
\hline $\begin{array}{l}\text { Length } \\
\text { (m) }\end{array}$ & $\begin{array}{c}\text { Width } \\
(\mathbf{m})\end{array}$ & $\begin{array}{c}\text { Depth } \\
(\mathbf{m})\end{array}$ & $\begin{array}{l}\text { Width of } \\
\text { each hull } \\
(\mathrm{m})\end{array}$ \\
\hline 1.85 & 1.52 & 0.5 & 0.32 \\
\hline
\end{tabular}

By knowing the specs of the hull (Table 2) is possible with the help of a software CAD to generate the hull mesh in different points of view. The importance of this part is to saw in perspective the design model and change or adjust different parameters.

Fig. 4. Displacement and planning hull [1].

\section{Two types of hulls}

\section{Displacement hulls}
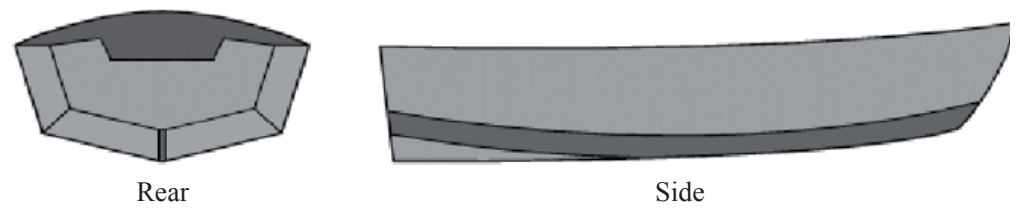

Planning hulls
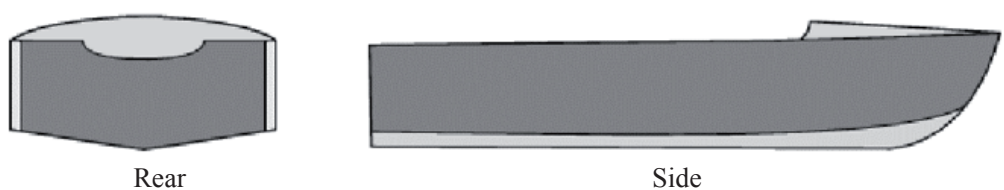
Fig. 5. First catamaran design in a software CAD.

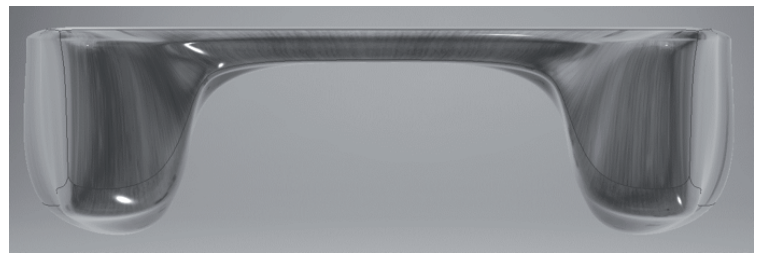

Fig. 6. Lines of the design in the software CAD.

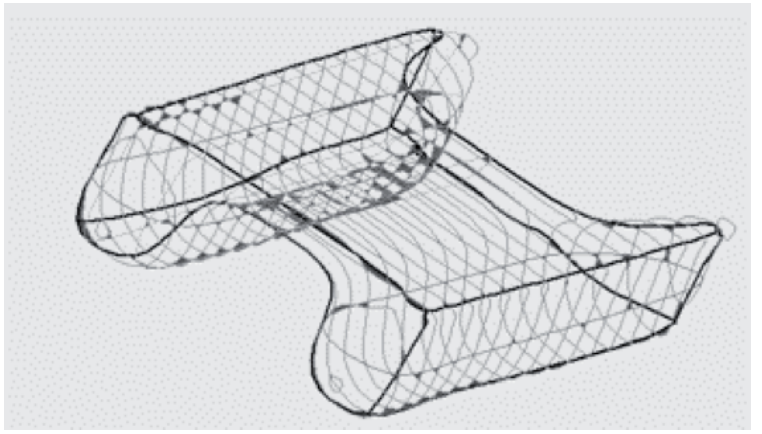

\section{Process design}

The CAD software used was Inventor, which presented the best tools to represent and export the model of the catamaran. The tool used in the program was FreeForm, which offers symmetry and mesh generation functions.

Fig. 7. Freeform catamaran design.

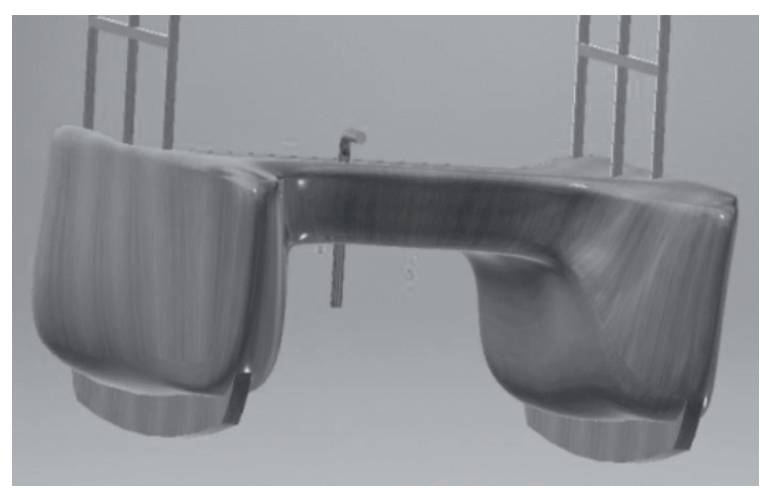

Having the hull design ready is necessary to open the design in the software Maxsurf, to analyze his stability; for this the help of the software Rhynoceros was important to scale the design and correct the tridimensional position of the vessel model. And finally export it to Maxsurf to analyze.
Fig. 8. View in maxsurf of the catamaran.

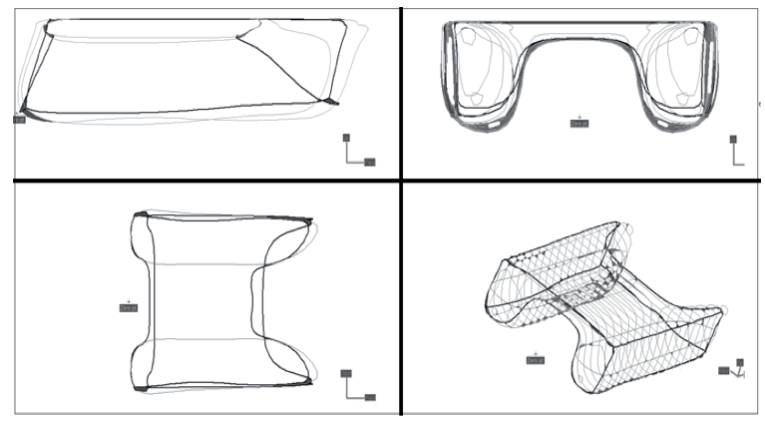

\section{Hydrostatics and stability}

\section{Calculation of areas}

The software CAD can calculate the total area of the catamaran, this is important to know the weight of the hull and the amount of material needed.

The hull weight was interpolated by a piece of the composite material proposed. The piece manufactured in the laboratory was of $\left(25^{*} 70\right.$ cm), Fig. 9.

Fig. 9. Piece of composite material witch ichu.

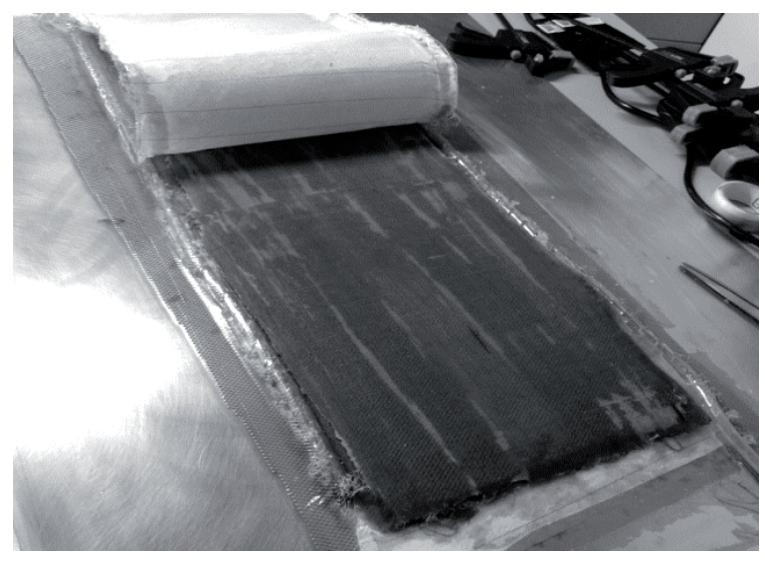

The total area of the hull of the catamaran was estimated in $6.121 \mathrm{~m}^{2}$, obtained by software Maxsurf.

The estimated weight of the hull was obtained as $29.845 \mathrm{~kg}$. 


\section{Center of Gravity}

This process represents a challenge not only because some software required a manually calibration, because after include all the components that are going to be on the boat it must state in equilibrium in the water [16].

This conditions in boats greater than 10 meters is not a problem, but in small recreational boats present some challenges. [5]

With the correct distribution of the components the problems of trim, where solved. The center of gravity of the hull, and the center of gravity of all the components had to be close to succeed in this part.

Fig. 10. Longitudinal instability (TRIM).

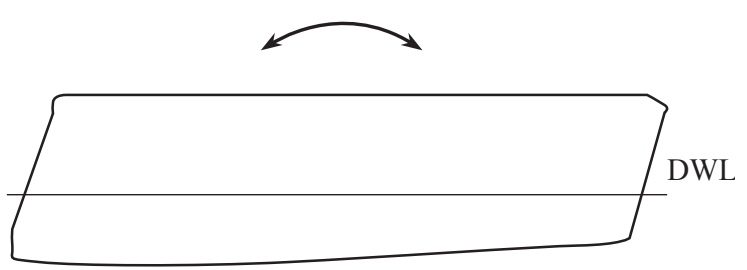

\section{Weight distribution on the boat}

This process is crucial to determine all the component that are going to be or could be on the boat and knowing the total weight.
The length of the catamaran was only 1.8 meters and due to the presence of solar panel, a high weight it was necessary to add against weight and a keel to balance the boat longitudinally.

In Table 3, is considering as $5 \mathrm{~kg}$ the aquatic plants expected to extract, this is because the catamaran it's not going to be carrying any undergrowth, instead the designed system installed in the bottom on the hull is going to drag the vegetation.

Where $L c$, is longitudinal coordinate and $V c$, is the vertical coordinate; Dead Weight, total amount of weight that is always on the boat; Dry Weight, total weight that depend of crew and Load.

\section{Draught water line}

Helped by the Archimedes principle it was determined the water line (Draught) Table 4., in two circumstances, with the dead and dry weight for freshwater (density $1000 \mathrm{~kg} / \mathrm{m}^{3}$ ), considering the regulation of minimum bulkhead [10].

Table 4. Weight and distance from the baseline.

\begin{tabular}{|c|c|c|}
\hline $\begin{array}{l}\text { Catamaran } \\
\text { Condition }\end{array}$ & $\begin{array}{l}\text { WEIGHT } \\
(\mathbf{k g})\end{array}$ & $\begin{array}{c}\text { Draught or } \\
\text { Water lines }(\mathbf{m})\end{array}$ \\
\hline Dead Weight & 227 & 0.17 \\
\hline Dry Weight & 307.6 & 0.23 \\
\hline
\end{tabular}

Table 3. Catamaran Components.

\begin{tabular}{|c|c|c|c|c|}
\hline & Components & Mass (kg) & $\mathbf{L c}(\mathbf{m})$ & $\mathrm{Vc}(\mathrm{m})$ \\
\hline \multirow{8}{*}{ Dead Weight } & Hull & 30 & 0.85 & 0.23 \\
\hline & Motor & 15 & 0.1 & 0.25 \\
\hline & Battery & 25 & 0.2 & 0.1 \\
\hline & Solar Panels & 28 & 0.6 & 0.95 \\
\hline & Support Structure & 14 & 0.5 & 0.8 \\
\hline & Keel & 57 & 1.2 & -0.065 \\
\hline & Props & 20 & 0.3 & 0.55 \\
\hline & Against Weight & 38 & 1.7 & 0.23 \\
\hline \multirow{2}{*}{ Dry Weight } & Crew & 75 & 0.85 & 0.25 \\
\hline & Aquatic plants & $5^{*}$ & 0.6 & 0.25 \\
\hline TOTAL & & 307 & 0.76 & 0.267 \\
\hline
\end{tabular}


Fig. 11. First catamaran design in a software CAD.

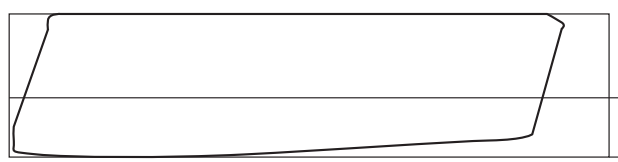

DWL

Baseline

\section{Transverse stability}

A concept in terms of boat stability, in which it explains the distance from the center of gravity $(G)$ should be always above the center of buoyancy (B). This is because when the boat make a heel move, a moment arm given by the distance (GZ) from center of buoyancy and the new center of buoyancy (B') formed when the boat moved transversally; when the moment arm is 0 o negative the boat lost the lateral stability [1], [5], [6].

\section{Type of design category}

The strictness and limit values to achieve in the stability and safety simulations are going to be determined by the design category of the boat [4], [6]. In Table 5 is shown the common operation areas and wave height depending of the design category.

The catamaran is going to operate in recreational lakes in optimal conditions, because of that the boat is going to be ruled by the design category type D.

Fig. 12. Important components in transverse stability.

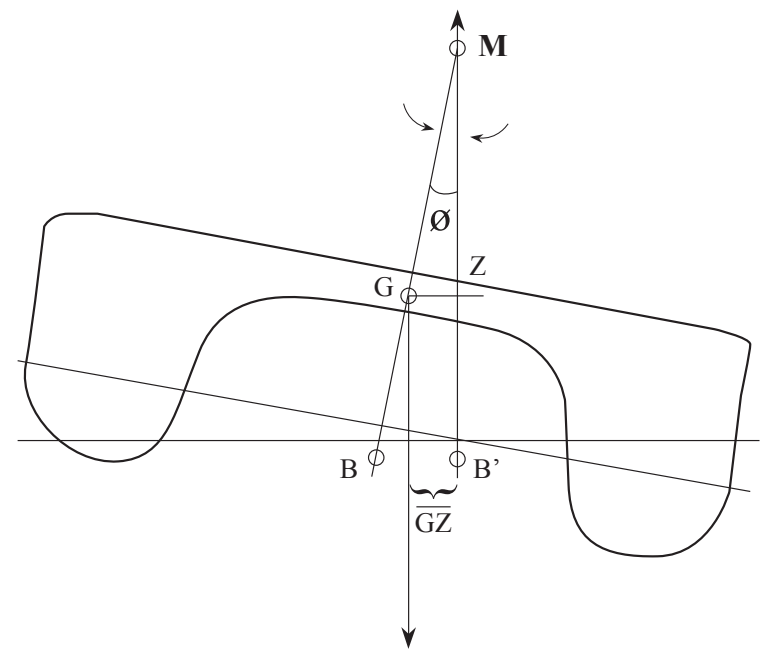

Table 5. Boat Design Category Conditions [4].

\begin{tabular}{|c|c|c|}
\hline Design Category & Operation & Wave Height \\
\hline A & Oceanic & $<8 \mathrm{~m}$ \\
\hline B & High Seas & $<4 \mathrm{~m}$ \\
\hline C & Coastal Waters & $<2 \mathrm{~m}$ \\
\hline D & Protected Waters & $<0.3 \mathrm{~m}$ \\
\hline
\end{tabular}

Fig. 13. Stability Graph of the design.

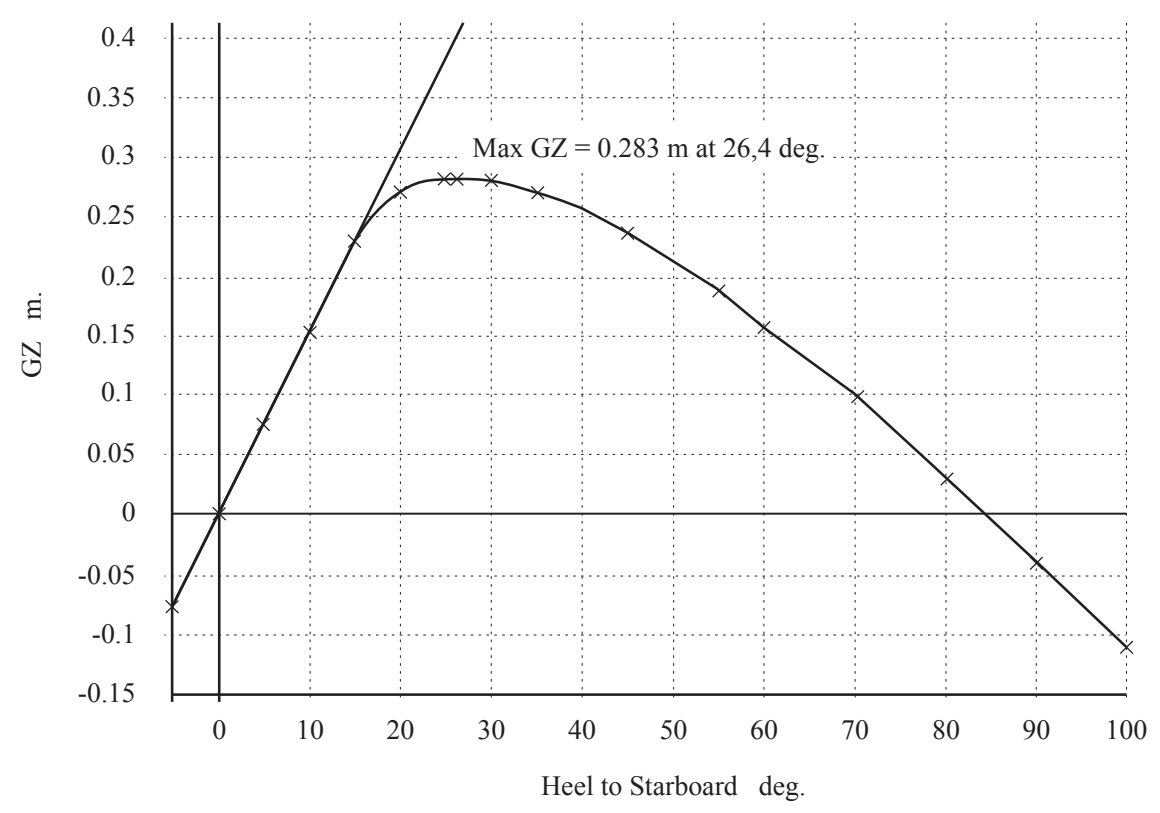




\section{STIX Analysis}

One important criteria for different types of boats is the STIX analysis, these criteria analyze the form of the boat with the stability, this calculation take as inputs the dimensions of the boat, righting moment curve, as well as the approximate weight and the water line [2].

The number obtained by the design after solving the analysis, should be greater that Minimum STIX value, given depending of design category.

The STIX values of the catamaran obtain by software was 5.7, so it passed the STIX analysis (Table 7).

With the main dimensions of the yacht and its righting moment curve, STIX uses the demotions of the boat to proposes an equation which value obtained by the design must be grated than the value stablished for each one of the design categories.

Table 6. Limit alues of STIX depending of the design category [16].

\begin{tabular}{cccccc} 
Design Category & A & & B & C & D \\
\cline { 5 - 6 } & Minimum STIX value & 32 & 23 & 14 & 5 \\
\hline
\end{tabular}

\section{The IMO standard, code intact stability}

IMO, an organization that manages the critical values of the stability criteria for different types of yachts, such as fundamental principles of precaution and righting level. They develop different types of precautions to take care of depending the vessel you are designing.

\section{Eco - Friendly manufacture}

As part of the eco-friendly solution that the project purpose, the hull is being made of natural fibers of ichu, a plant that grown above 3000 m.a.s.l. However, to be able to use this plant as a material is necessary a process where the lignite is removed of the plant by an alkaline process that requires about 5 hours and the final result in longitudinal fiber of ichu Fig. 16 [18].

The boat hull using natural fiber in his configuration, Fig. 15, is planned to be fabricated in a laboratory with a determined process to adhere the fibers with the polyester resin, that is compatible with the fiber of ichu. Nowadays there are different methods to the adhere the mention materials, each one achieving better uniformly properties around the surface, like vacuum chamber, spray lay-up and hand lay-up [17].

However, because the size of the catamaran and that the hull itself doesn't handles critical forces, the method of manufacture recommended is the hand land lay-up (In case of increasing the dimensions or interacting with more critical forces the manufacture method selected would be under vacuum test) [17].

Table 7. Values of the stability simulations, considering the design category and de catamaran design.

\begin{tabular}{|c|c|c|c|c|c|}
\hline Test & $\begin{array}{c}\text { Value } \\
\text { Obtain }\end{array}$ & $\begin{array}{l}\text { Value by } \\
\text { standard }\end{array}$ & Status & Margin & Units \\
\hline STIX & 5.7 & 5 & PASS & 0.7 & \\
\hline Angle of maximum GZ multi hull & 26.4 & 25 & PASS & 1.4 & deg. \\
\hline Initial GMt & 0.869 & 0.15 & PASS & 0.7 & $\mathrm{~m}$ \\
\hline Area 0 to 30 or $\mathrm{GZ}$ max & 5.7609 & 3.1513 & PASS & 2.6 & m.deg \\
\hline Area 30 to 40 & 2.6848 & 1.7189 & PASS & 1.0 & m.deg \\
\hline Range of positive stability & 84 & 7 & PASS & 77.0 & $\operatorname{deg}$ \\
\hline Passenger crowding & 1.4 & 10 & PASS & -8.6 & deg \\
\hline
\end{tabular}


Fig. 15. Ichu growing in Cusco, Perú.

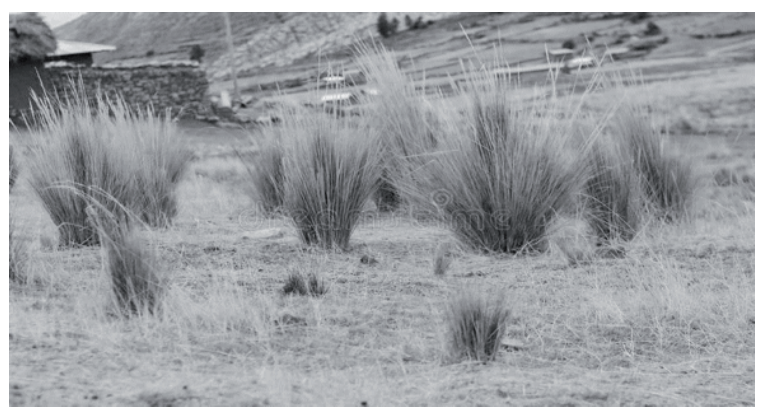

Fig. 16. Longitudinal natural fiber of ichu in seal package [18]

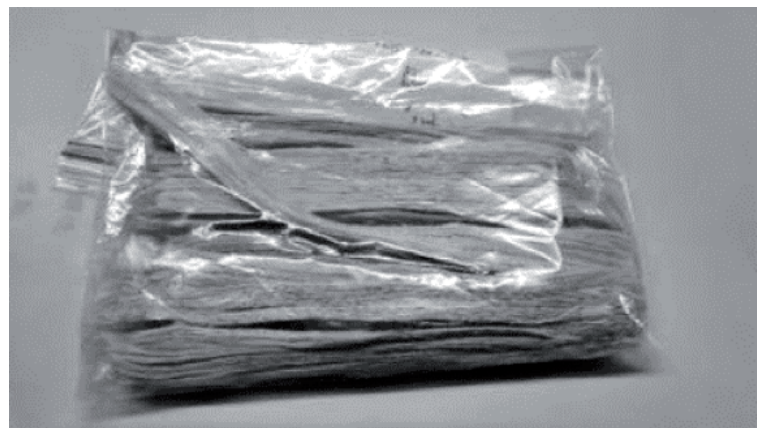

\section{Organization of the materials}

One of the functions of the hull of the vessel is to displace water, so that the vessel by hydrostatic principles could float, the displaced volume generates a pressure on the hull and the composite material, the material must handle this pressure. This pressure generated by the water to the vessel is obtained by the Equation 1 [1].

$$
P b=\frac{0.1 * m}{L w l * B c} *(1+n c g) * k a r * k l \frac{k N}{m^{2}}
$$

The maximum value of $P b$ was obtain in the lower part of the stern, the bottom of the ship, after analyzing in different points.

The maximum pressure that the vessel requires to handle is $7.83 \mathrm{kPa}$.

Using the configuration in Fig. 17, the next procedure was to determine if it was going to handle the pressure obtained. Considering a surface of $25 * 70 \mathrm{~cm}$ and the unitary properties the Ichu as $350 \mathrm{MPa}$ (longitudinal fiber with alkaline process) [18]. Using a software of finite elements and stablishing the orientation of the fibers (Fig.17) it was obtained that the surface could handle approximately $20 \mathrm{KPa}$.

Fig. 17. Sandwich proposed configuration.

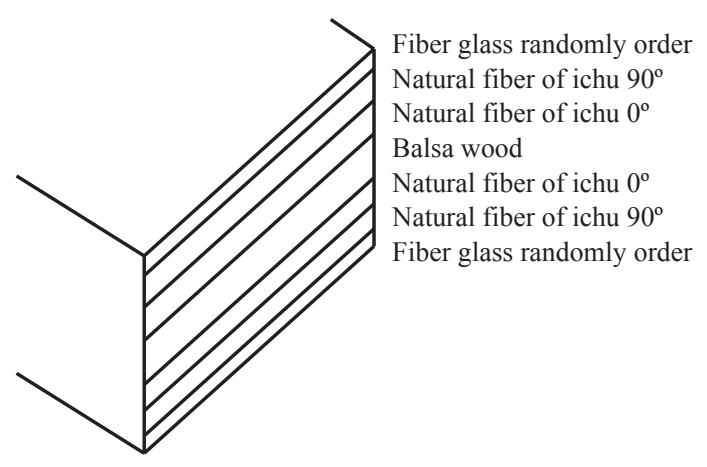

Fig. 18. Analysis in finite element software.

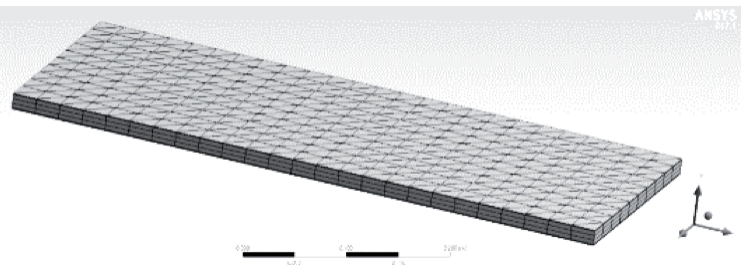

\section{Structural Resistance}

In order to conserve the structural resitance through time and normal use, the catamaran have an intern structure, that helps the composite material exterior layers to resist side collitions and the impacts with other boats or plataforms.

Fig. 19. Structural frame of the catamaran.

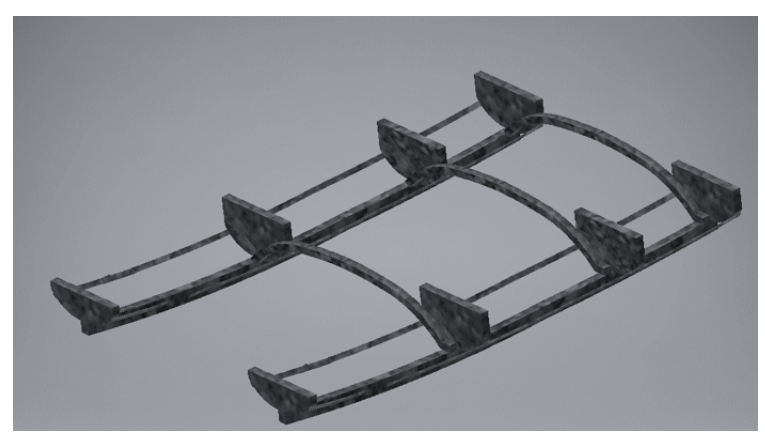


Fig. 20. Final design of the catamaran.

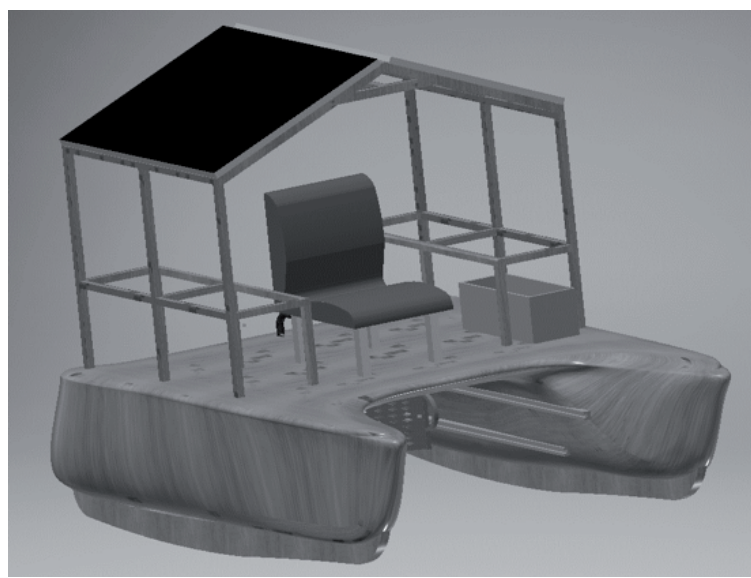

\section{Extraction system}

With the extraction and recollection system, is planned to use a mesh strainer, and take advantage of the particular form of the catamaran.

Fig. 21. Extraction system.

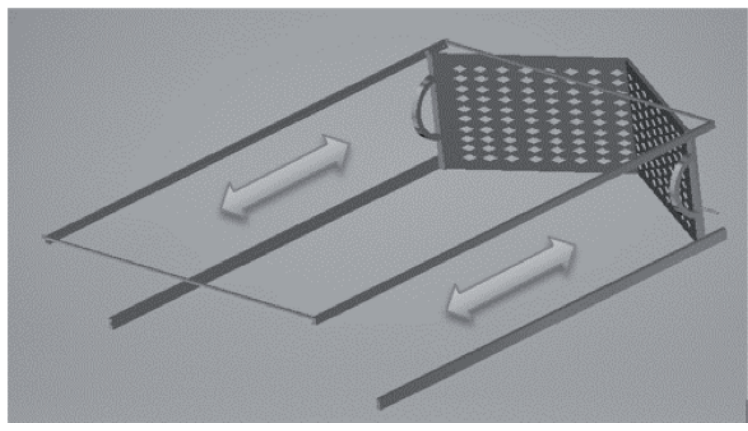

Fig. 22. Extraction system installed the catamaran.

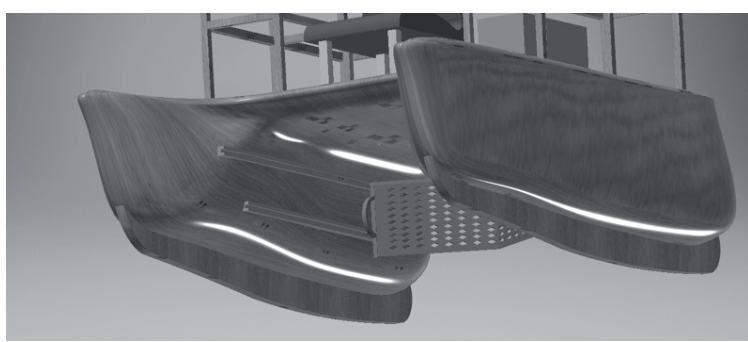

The system takes advantage of the forward inertia of the boat to position itself to the back of the catamaran and while the catamaran moves around the lake it collect and displace the duckweed, until the volume between the keels is full. To extract the aquatic waste, the crew member just need to pull the frame of the mesh and collocate the duckweed in plastic bags to use them as fertilizer.

The maximum volume of seaweed that the catamaran could manage to extract is $0.0614 \mathrm{~m}^{3}$, this value depends of the size of the duckweed.

Fig. 23. Volume of duckweed planned to extract.

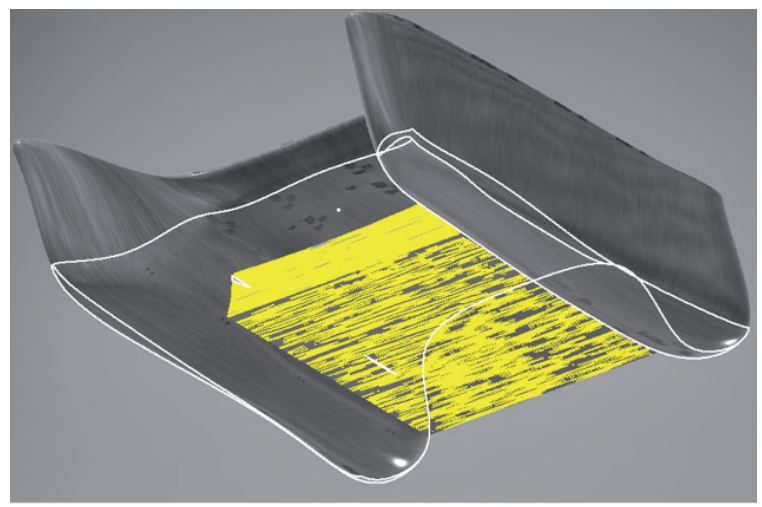

\section{Motor Estimation Power}

To estimate the power required in the boat, first is important to establish the velocity that it has to reach. Mostly in small lakes, the maximum speed reached by small vessel is four knots [16].

From that point, it was necessary to use a power prediction method. For small dimensions' catamarans it could be used a monohull power prediction method as Van Oortmerssen [13], [19]. The method consists in interact the resistance of the

Fig. 24. Van Oortmerssen deduces a factor from the wave pattern along the hull and consider the length of the boat.

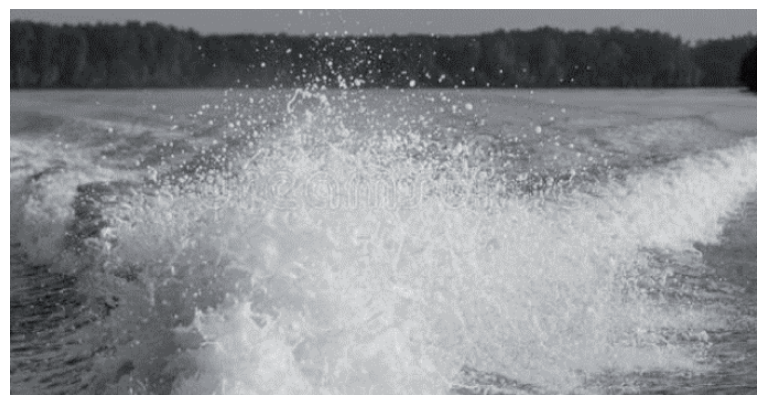


Fig. 25. Graphic, speed of the boat vs power required.

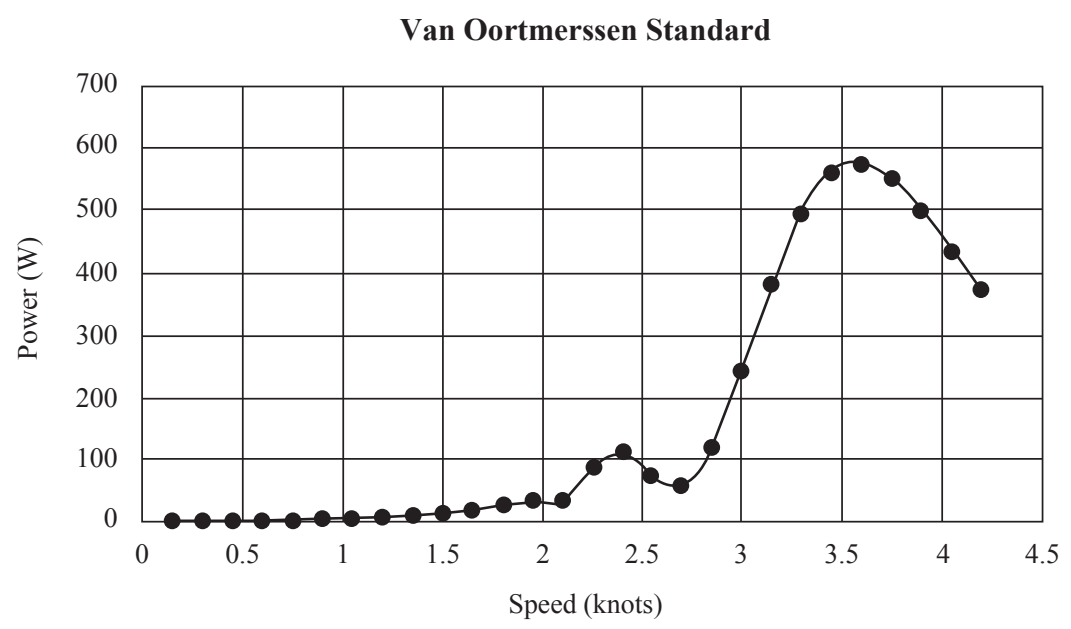

water, the displacement capacity, the form of the wave made by the ship passing through and estimate the power required for different speeds [13].

In Fig. 25 is shown the graph generated by Maxsurf resistance and how due drag forces the vessel requires certain power to exceed the 2.3 and the 3.55 knots, but then needs less power to obtain more speed.

Is important to considerate the maximum safety speed approximation by the length of a boat in perfect conditions, Equation 2 [1].

$$
V \max =2.4 *(L)^{0.5}
$$

The maximum safety speed that the catamaran could achieve is 3.29 knots, approximately the

Fig. 26. Wave pattern when the catamaran pass thought.

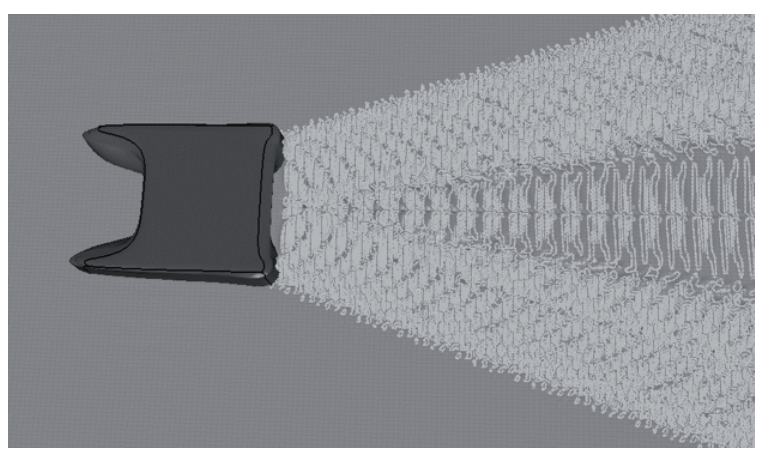

minimum power required for that speed is $400 \mathrm{~W}$.

An electric outboard propeller motor of $480 \mathrm{~W}$, manufactured by Intex was the engine selected for the catamaran.

\section{Solar Panels}

In order to achieve one of the most important objectives of the project, the boat must have a power system that is energy friendly to the environment, for this the use of solar energy was chosen. Once selecting solar panels as the main source of power, it is important to consider the number of hours that the ship is going to operate.

By using a boat for the labor of extracting duckweed the estimated time of operation for the cleaning considering the dimensions of the catamaran is in Equation 3.

The recreational lake selected is located in the city of Lima and has a surface area of $125 \mathrm{~m}^{2}$.

$$
\text { Est.time of cleaning }=0.02 \frac{\text { hours }}{m^{2} \text { of the lake }}
$$

The catamaran will be equipped with 2 conventional 12 Volt batteries, Table 8 . 
Table 8. Selection of battery voltage considering power requirements [11].

\begin{tabular}{|c|c|}
\hline $\begin{array}{l}\text { POWER REQUIRED } \\
\text { (W) }\end{array}$ & $\begin{array}{l}\text { NOMINAL TENSION } \\
\text { OF THE BATTERY (V) }\end{array}$ \\
\hline $0-800$ & 12 \\
\hline $800-1600$ & 24 \\
\hline $1600-3200$ & 48 \\
\hline
\end{tabular}

To select the capacity of the solar panel, it was used the Equation 9.2. The variables where the consumption per day, a safety factor of twentyfive percent, the amount of radiation present in the place (HSE) and the efficiency of the electrical components (90\% was used) [11].

Power of the solar panel $(W p)=\frac{1.25 * \text { Consume }\left(\frac{W h}{\text { day }}\right)}{H s e\left(\frac{h}{\text { day }}\right) *(\text { Efficiency })}$

Table 9. Variables for the Formula 4.

\begin{tabular}{|c|c|c|}
\hline Data required & & Units \\
\hline Use & 2.5 & $\mathrm{~h}$ \\
\hline Power required & 480 & W \\
\hline Consume & 1200 & Wh/day \\
\hline HSE min. & 4.35 & h/day \\
\hline Solar panel power required & 362.97 & W \\
\hline
\end{tabular}

\section{Conclusions}

By applying the appropriate equations, it was possible to design an ecological catamaran using composite materials with natural fibers (Ichu) for the construction of the hull and the configuration of the equipment for the renewable energy source.

The critical values for the stability and security analysis were given for different standards that vary according the type of vessel, dimensions, max. speed, application; So before starting any boat design is important to stablish the mentioned factors.

The system that collect and extract aquatic plants (duckweed) attached to the catamaran, is a perfect option for recreational lakes that have a heavy
Fig. 27. Electric diagram of the components in the ship.

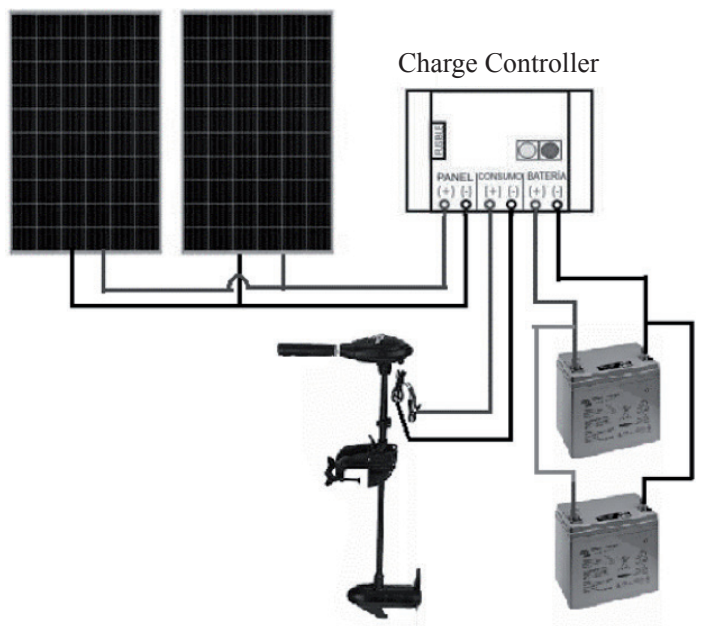

amounts of organic on inorganic floating waste, because it is perfect size, secure, stable, ecofriendly. However, by increasing the dimensions of the design and re-engineering their components it could be used as an alternative to cleaning the garbage patches in our oceans.

\section{References}

[1] LARS LARSON, ROLF ELLISON. "Yacht Design" London, 2000.

[2] ROBERT STEWARD. "Boat Building Manual” USA, 2014.

[3] DANIEL CAO CHIEW. "Diseño y cálculo de una embarcación sin licencia de $5 \mathrm{~m}$ de eslora" España 2016.

[4] ANTONIO GALLARDO MARTÍNEZ. "Programación de las normas ISO 12217-1 (2011) e ISO 12217-3 (2011) para el estudio de la estabilidad y flotabilidad de embarcaciones de recreo" España, 2013.

[5] GONZÁLEZ, HARRY. "Estabilidad estática transversal”, 2011.

[6] PABLO SÁNCHEZ RODRÍGUEZ. "Diseño de una embarcación de 7 metros de Loa" España, 2013. 
[7] BUSTO RODRÍGUEZ, MANUEL RAMÓN. "Diseño de proceso de fabricación de un catamarán de fibra de vidrio en astillero", México, 2008.

[8] YEBRA FOLGUERAL, FRANCISCO DANIEL. "Diseño y cálculo de una embarcación sin licencia de $5 \mathrm{~m}$ de eslora”.

[9] SOUMYA, CHAKRABORTY. "Naval Architecture", USA, 2017.

[10] "Reglamento nacional para la asignación de francobordo para embarcaciones".

[11] GARAYSALAZAR, ROLAND "Instalaciones Solares Fotovoltaicas, Aplicaciones en baja potencia.”. Perú.

[12] MENESES ROQUE, PEDRO ANATAEL. "Construcción y reconocimiento de embarcaciones de recreo”, Espańa, 1995.

[13] G. VAN OORTMERSSEN. "A power prediction method and its application to small ships".
[14] ARROYAVE, MARÍA DEL PILAR "La lenteja de agua: una planta acuática promisoria" Colombia, 2004.

[15] ULRICH, KARL T. "Product Design and Development" 2012.

[16] TORRALBO GAVILÁN, JORDI "Análisis y propuesta de mejora de la seguridad en las embarcaciones de recreo a través de los datos obtenidos en sus reconocimientos e inspecciones” España, 2015.

[17] STUART, WILLIAM JOSEPH "Composite Materials Layup Lab” Usa.

[18] S. Charca, M. E. F., R. L., S. C., "Caracterización mecánica de las fibras tecnicas Ichu y Cbuya” Departamento de Ingeniería Mecánica Y Departamento de Ingeniería Química, Universidad de Ingeniería y Tecnología, Lima, 2017.

[19] DANISMAN, DEVRIM. "A Practical Power Prediction of an Asymmetric Catamara n Hull Form”, 2005. 
